\title{
Hoe hou je het vol?!
}

\author{
Citation for published version (APA):
}

Janssen, J. H. L. J. (2019). Hoe hou je het vol?! Proces: tijdschrift voor strafrechtpleging, 98(4), 239-241. https://doi.org/10.5553/PROCES/016500762019098004001

\section{DOI:}

10.5553/PROCES/016500762019098004001

Document status and date:

Published: 01/01/2019

Document Version:

Publisher's PDF, also known as Version of record

Please check the document version of this publication:

- A submitted manuscript is the version of the article upon submission and before peer-review. There can be important differences between the submitted version and the official published version of record. People interested in the research are advised to contact the author for the final version of the publication, or visit the DOI to the publisher's website.

- The final author version and the galley proof are versions of the publication after peer review.

- The final published version features the final layout of the paper including the volume, issue and page numbers.

Link to publication

\section{General rights}

Copyright and moral rights for the publications made accessible in the public portal are retained by the authors and/or other copyright owners and it is a condition of accessing publications that users recognise and abide by the legal requirements associated with these rights.

- Users may download and print one copy of any publication from the public portal for the purpose of private study or research.

- You may not further distribute the material or use it for any profit-making activity or commercial gain

- You may freely distribute the URL identifying the publication in the public portal.

If the publication is distributed under the terms of Article 25fa of the Dutch Copyright Act, indicated by the "Taverne" license above, please follow below link for the End User Agreement:

https://www.ou.nl/taverne-agreement

Take down policy

If you believe that this document breaches copyright please contact us at:

pure-support@ou.nl

providing details and we will investigate your claim.

Downloaded from https://research.ou.nl/ on date: 26 Apr. 2023

\section{Open Universiteit}




\section{Hoe hou je het vol?!*}

Janine Janssen

Gezien de populariteit van politieseries zou de indruk kunnen ontstaan dat niets zo ontspannend is als werk in de veiligheidszorg. Wie zit er na een dag hard werken nu niet graag onderuitgezakt thuis op de bank te genieten van een spannende film? Daar waar ons op tv het werk in de veiligheidszorg als onderhoudende hapklare brokken wordt gepresenteerd, is de realiteit echter een andere. Uit cijfers van het Centraal Bureau voor de Statistiek blijkt bijvoorbeeld dat hulpverleners van de brandweer en van de politie van alle beroepsgroepen het hoogste ziekteverzuim hebben. In 2017 was gemiddeld 8,1\% van de personeelssterkte ziek. De gemiddelde politieagent was van elke honderd werkdagen acht dagen ziek. Een deel van het hoge verzuim komt door langdurig zieke werknemers. Bij één op de zes politie- en brandweermensen duurde het meest recente verzuim meer dan vier weken. Een algemeen directeur heeft een gemiddeld verzuim van $1,4 \%$. Hoewel bij deze cijfers enige nuanceringen passen - met een gebroken been kan wel kantoorwerk worden gedaan, maar niet een brandweerladder worden bestegen,$-{ }^{1}$ baren deze cijfers toch zorgen. Want we verwachten nogal wat van professionals in de veiligheidszorg. Ze houden zich bezig met preventie, aanpak, opsporing en vervolging van vaak complexe casuïstiek. Handhaven in een zaak van huiselijk geweld of de begeleiding van een zedendelinquent vraagt niet alleen inhoudelijk iets van een professional. Die moet uiteraard kennis van de inhoud van de problematiek hebben en daarnaast weten hoe de veiligheidszorg in elkaar steekt en dus weten met wie en hoe er verder samengewerkt moet worden. Een en ander vraagt ook iets van de professional als mens. Hoewel oordelen in ons systeem een taak van de rechter is, wordt die professional dagelijks met zaken geconfronteerd waar hij of zij als mens ook een morele visie op heeft. Het is uiteraard een vereiste van professionaliteit om persoonlijke voor- of afkeuren voor je te houden, maar het kan toch allemaal te veel worden als je dag in dag uit met de negatieve aspecten van de samenleving wordt geconfronteerd.

Waar het om gaat is dat een professional weerbaar is, dat wil zeggen dat hij of zij in staat is om onder moeilijke omstandigheden te kunnen blijven functioneren.

* Prof. dr. Janine Janssen is hoofd onderzoek van het Landelijk Expertise Centrum Eer Gerelateerd Geweld van de Nationale Politie, lector Veiligheid in Afhankelijkheidsrelaties aan Avans Hogeschool, bijzonder hoogleraar Rechtsantropologie aan de Open Universiteit en tevens voorzitter van de redactie van PROCES.

1 https://beveiligingnieuws.nl/nieuws/brandweer-en-politiemensen-hebben-hoogsteziekteverzuim. 
Weerbaarheid kent verschillende elementen. Een professional moet fysiek in staat zijn zijn of haar taak uit te oefenen. Mentaal dient een professional grip te hebben op de eigen taken om onder uitdagende omstandigheden te kunnen functioneren. En tot slot is ook moreel grip nodig om goed te kunnen werken. Het gaat in dit verband ook om zingeving en integriteit. Al die verschillende aspecten van weerbaarheid dienen met elkaar in balans te zijn. We hebben niks aan professionals die alleen fysiek hun mannetje staan, mentaal en moreel moet ook een en ander op orde zijn. ${ }^{2}$ Hoewel in de veiligheidszorg inmiddels ook allerhande vormen van techniek hun entree hebben gevonden, blijven mensen toch het grootste goed: het is mensenwerk. We moeten dan ook zuinig blijven op al die professionals. Ten burele van de redactie verzuchten wij ook wel eens 'hoe houden ze het vol?!' als we de stukken lezen die ons worden voorgelegd over de beroepspraktijk. Om die reden heeft de redactie van PROCES besloten een themanummer aan de weerbaarheid van de professional te wijden. We doen dat niet zoals nu ook in het debat over pensioenen gebeurt over de vraag of zwaar belaste mensen eerder zouden moeten stoppen met werken. ${ }^{3}$ We richten ons op het hier en nu: wat speelt er momenteel en wat zou er in het hier en nu moeten gebeuren of waar zou rekening mee moeten worden gehouden om een en ander voor professionals werkbaar te maken en te houden? Hiervoor zijn verschillende aspecten van weerbaarheid kort aangestipt. Op de fysieke weerbaarheid na komen die diverse betekenissen van weerbaarheid in dit themanummer aan bod.

Allereerst leggen we een relatie met kenmerken van casuïstiek die door professionals behandeld wordt. Martina Althoff, Janine Janssen en Anne-Marie Slotboom gaan in op de vraag waarom het ook voor de weerbaarheid van professionals belangrijk is dat zij goed inzicht hebben in genderverhoudingen bij de aanpak van veiligheidsvraagstukken. Julia Wilpert, Marije Keulen-de Vos, Minne De Boeck en Kasia Uzieblo brengen verslag uit van een symposium over de impact van het werken met zedenplegers op professionals. Sylvia van Dooren, Janine Janssen, Emile Kolthoff en Nanne Vosters zoomen tot slot in op de relatie tussen huiselijk geweld en georganiseerde misdaad. Het komt voor dat zich huiselijk geweld afspeelt in kringen die ook betrokken zijn bij zware vormen van criminaliteit. Wat komt er dan zoal kijken bij de samenwerking tussen verschillende schakels in de veiligheidszorg? Wat betekent het aanpakken van dit soort meervoudige complexe casuïstiek voor de weerbaarheid van de professional?

Daarna staan we stil bij verschillende schakels in de veiligheidszorg. In het PROCESperikel vertelt Petra Weijman over haar werk in het gevangeniswezen. Vivienne de Vogel en Jacqueline Bosker nemen ons mee naar het forensisch sociale domein, en Henk Sollie naar de politie. Mustapha Aoulad Hadj, Rob Straver en Janine Janssen staan stil bij het werk van de sociale professional. Margriet Maris introduceert ons bij de vertrouwenspersonen. Tot slot vraagt Jeroen ten 
Voorde zich in het PS van een redacteur, naar aanleiding van de ontwikkelingen in Polen, af hoe het met de weerbaarheid van rechters is gesteld. 